\title{
DISTRIBUTION AND QUANTITATIVE ASSESSMENT OF WORLD CRUDE OIL RESERVES AND RESOURCES
}

Charles D. Masters, US Geological Survey, Reston, Virginia 22092, USA; David H. Root, US Geological Survey, Reston, Virginia 22092, USA; William D. Dietzman, Energy Information Administration, Dallas, Texas 75242, USA.

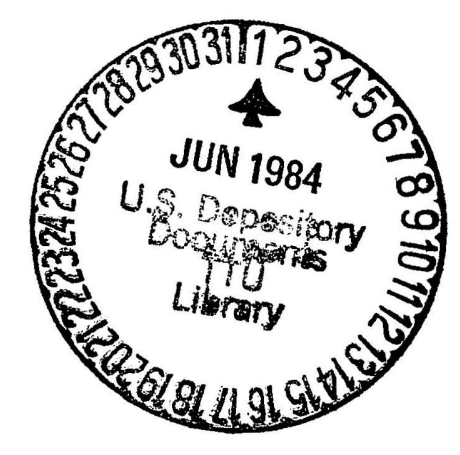

PREPRINT OF PAPER PRESENTED TO THE WORLD PETROLEUM CONGRESS

LONDON

AUGUST 28 TO SEPTEMBER 2, 1983 



\title{
DISTRIBUTION AND QUANTITATIVE ASSESSMENT OF WORLD CRUDE OIL RESERVES AND RESOURCES
}

\author{
Charles D. Masters, US Geological Survey, Reston, Virginia 22092, USA; David H. Root, \\ US Geological Survey, Reston, Virginia 22092, USA; William D. Dietzman, Energy \\ Information Administration, Dallas, Texas 75242, USA.
}

\begin{abstract}
A bstract. World demonstrated reserves of crude oil are approximately 103 gigatonnes of oil (GTO). Cumulative production is 64 GTO and annual production is 2.9 GTO. Demonstrated reserves of crude oil have declined over the past 10 years as have discoveries, while production has lagged over the same period. The assessment of undiscovered resources shows a $90 \%$ probability that the amount discoverable lies between 46 and 202 GTO, 79 GTO being the most likely value. The most likely value for ultimate recoverable resources is 246 GTO. The distribution of ultimate resources of crude oil will remain highly skewed toward the Middle East; no frontier areas with large enough potentials to significantly affect present distribution have been recognized. Rates of discovery have continued to decline over the past 20 years even though exploration activity has increased in recent years. Prudence dictates, therefore, that the low side of the assessment of undiscovered resources be responsibly considered and that alternative energy sources be a part of future planning.

Extra-heavy oil and bitumen are assessed separately, with reserves being figured as the annual productive capacity of installed facilities times 25 years. The annual production of extra-heavy oil is about 1.1 million tonnes and of bitumen about 8 million tonnes.

Résumé. Les réserves mondiales démontrées de pétrole brut s'élèvent à environ 103 gigatonnes de pétrole (Gtp). La production cumulée est de $64 \mathrm{Gtp}$ et la production annuelle est de $2.9 \mathrm{Gtp}$. Les réserves démontrées de pétrole brut ont diminué depuis 10 ans ainsi que les découvertes, et la production est restée à la traîne pendant la même période. L'évaluation des ressources non découvertes montre, avec une probabilité de $90 \%$, que la quantité découvrable est situé entre 46 et $202 \mathrm{Gtp}, 79 \mathrm{Gtp}$ étant la valeur la plus probable. La valeur la plus probable des ressources ultimes récupérables est de $246 \mathrm{Gtp}$. La répartition des ressources ultimes de pétrole brut continuera de favoriser le Moyen-Orient; aucune des zones nouvelles découvertes ne s'est révélée suffisamment prometteuse pour influencer la répartition actuelle. Les taux de découvertes ont continué à décroître depuis 20 ans malgré l'augmentation des activités d'exploration au cours des dernières années. La prudence recommande donc de prendre en considération le côté bas de l'évaluation des ressources non découvertes et de tenir compte des sources énergétiques de remplacement dans la planification future.

L'évaluation des huiles très lourdes et du bitume est faite à part, les réserves étant définies comme 25 fois la capacité productive annuelle des équipements installés. La production annuelle des huiles très lourdes est d'environ 1.1 million de tonnes et celle du bitume d'environ 8 millions de tonnes.
\end{abstract}

\section{INTRODUCTION AND DEFINITIONS}

The enumeration of world crude oil reserves and resources is a difficult undertaking. One must rely on data gathered by others and, through various spotcheck and cross-check mechanisms, distinguish the reasonable from the unreasonable. Estimating techniques vary, standards of measurement vary, classification of the reported elements differ and, in some cases, even the recognition of what is being reported is obfuscated by language and nomenclatural ambiguities. Therefore, to improve world petroleum resource understanding, it is prudent to describe the methodologies and measurement standards explicitly, to disaggregate the data as much as possible to gain insight into the source of the differences, and to standardize the classification and nomenclature schemes to establish unambiguous communication.

The purpose of this report is to give an estimate of world crude oil resources, their distribution, and their API gravity. The resource classification diagram of the US Geological Survey (USGS) and the US Bureau of Mines ${ }^{1}$ allows for the reporting of both reserves and resources with the degree of geologic certainty of the data expressed on the horizontal axis and the degree of economic potential expressed on the vertical axis. Utilizing this classification format, Fig. 1 shows the estimate for world resources of conventional crude oil. By conventional oil, we mean the oil greater than $10^{\circ} \mathrm{API}$ gravity (excluding natural 
AREA : WORLD

UNITS : $10^{9}$ TONNES

\begin{tabular}{|c|c|c|c|c|c|}
\hline \multirow{3}{*}{$\begin{array}{l}\text { CUMULATIVE } \\
\text { PRODUCTION } \\
\quad 64\end{array}$} & \multicolumn{2}{|c|}{ IDENTIFIED RESOURCES } & \multicolumn{3}{|c|}{ UNDISCOVERED RESOURCES } \\
\hline & DEMONSTRATED & \multirow{2}{*}{ INFERRED } & \multirow{2}{*}{\multicolumn{2}{|c|}{$\begin{array}{l}\text { PROBABILITY } \\
95 \% \quad \text { MODE }\end{array}$}} & \multirow{2}{*}{$\begin{array}{r}\text { Y RANGE } \\
5 \%\end{array}$} \\
\hline & MEASURED INDICATED & & & & \\
\hline ECONOMIC & $\begin{array}{l}\text { RESERVES } \\
103\end{array}$ & $\begin{array}{l}\text { INFERRED RESERVES } \\
\omega \\
\omega\end{array}$ & 46 & 79 & 202 \\
\hline $\begin{array}{l}\text { MARGINALLY } \\
\text { ECONOMIC }\end{array}$ & $\begin{array}{c}\text { MARGINAL RESERVES } \\
\text { EACH 1\% WORLD AVERAGE } \\
\text { RECOVERY INCREASE } \\
\text { EQUALS } 5\end{array}$ & $\begin{array}{l}\omega \\
\text { 出 INFERRED } \\
\text { MARGINAL RESERVES } \\
\ll\end{array}$ & & & \\
\hline $\begin{array}{c}\text { SUB- } \\
\text { ECONOMIC }\end{array}$ & \begin{tabular}{|} 
DEMONSTRATED \\
SUBECONOMIC RESOURCES \\
324
\end{tabular} & $\begin{array}{lc}0 & \text { INFERRED } \\
z & \text { SUBECONOMIC } \\
& \text { RESOURCES }\end{array}$ & 89 & 153 & 393 \\
\hline
\end{tabular}

OTHER

OCCUR-

RENCES

AUTHORS: MASTERS, ROOT, DIETZMAN
EXTRA-HEAVY OIL AND BITUMEN

DATE: IDENTIFIED RESOURCES AND

PRODUCTION: $1 / 1 / 81$

UNDISCOVERED RESOURCES : $3 / 83$

Fig. 1. Classification of world crude-oil resources. The subeconomic resources are based upon a weightedaverage recovery factor for conventional oil of $34 \%$. Units $=10^{9}$ tonnes ( 1 tonne $=7$ barrels).

gas liquids) which is broadly considered to be economically recoverable by conventional primary, waterflood, and pressure maintenance techniques; the extra-heavy oil (less than $10^{\circ}$ API and greater than 10000 centipoise) of the Orinoco Petroleum Belt of Venezuela and the bitumen of the Athabasca tar sands of Canada, for examples, are not included with conventional crude oil but are listed separately.

The resources of crude oil are classified as being Identified or Undiscovered. The left-half of Fig. 1 shows Identified (or 'Discovered') Resources. Economically recoverable Identified Resources are called Reserves and classified in three subdivisions: Measured Reserves (or Proved, of the US Energy Information Administration (EIA) ${ }^{2}$ are defined as the expected recovery, by conventional techniques, considering the full extent of each recognized reservoir; Indicated Reserves (or Indicated Additional as defined by American Petroleum Institute (API) ${ }^{3}$ ) are defined as the additional amount of oil that could be recovered given installation of conventional waterflood facilities; and Inferred Reserves are defined as the amount of oil derived from the expected growth in the reported size of fields, given the addition of new pools or reservoir extensions not envisaged in the Measured Reserve calculation. The combination of the Measured and Indicated Reserve is a Demonstrated Reserve. Industry custom prior to 1970 was to report Measured (or Proved) Reserves in the restricted sense of only what had actually received sufficient development drilling to permit reliable flow testing. Since then, however, it has become customary to report an estimate of the maximum expectable conventional recovery from the recognized reservoirs, whether or not they have been completely developed by drilling and whether or not they have 
been completely fitted for optimum water-flood recovery. Our definitions and estimates are consistent with current custom and are reported as Demonstrated Reserves. The remainder of the in-place crude oil may be defined as Sub-economic Resources, or if some portion of the remainder is judged to be economic under a specified set of conditions, it can be reported as Marginal Reserves. In effect, when we gain the capability to assess oil deriving from enhanced oil recovery (EOR)-i.e. recovery techniques other than those herein defined as conventional-the quantities likely will be identified initially as Marginal Reserves;. even though there is limited production from EOR, its low level of 11.6 million tonnes of oil per year (MTO/yr, 1 tonne $=7$ barrels) in the United States and $2.6 \mathrm{MTO} / \mathrm{yr}$ in the rest of the world ${ }^{4}$ suggests that the activity is still in the pilot-plant stage, so any estimates of potential reserves are premature.

The right side of the classification diagram (Fig. 1) shows subdivisions of the Undiscovered Resources based on the same principles as those considered in classifying Identified Resources. The estimate of the economically recoverable Undiscovered Resources is based, broadly, on existing price-cost relationships, and their quantity may be expressed graphically through a full range of probabilities; commonly we report two points on the range encompassing a $90 \%$ probability of occurrence, as well as the mode or most likely occurrence.

Other Occurrences of oil, which are defined as including both extra-heavy oil and tar sand (bitumen), are referred to at the bottom of Fig. 1. These resources are set apart from conventional oil at least in part because of their vastly different, technically achievable reserve to annual production ratios $(\mathrm{R} / \mathrm{P})$. The estimate for Other Occurrences of oil is discussed in a later section.

\section{METHODOLOGY FOR ASSESSMENT OF CRUDE-OIL RESERVES AND THEIR API GRAVIITIES}

Reserves were estimated by field and aggregated by country and by region (Table I). Prime sources of data were the well and field files of Petroconsultants S.A., scientific and trade literature, and government publications. Approximately $80 \%$ of world reserves, field-by-field, have been specifically examined by W. D. Dietzman and his colleagues with the EIA; they have estimated for each field the Demonstrated oil in place and the Original Reserves. (For an example of one of several publications, see Ref. 5.) The weigh- ted-average recovery factor from these studies is $34 \%$; this recovery factor includes only the conventional (primary plus waterflood and pressure maintenance) oil recovery. Approximately $20 \%$ of the world's known oil is in countries for which adequate field data were not available. In those countries reserves are estimated from available production data and from published national estimates. It is possible that the published estimates of national reserves correspond to a definition of reserves more strict than that used here. We have not compensated for this by adding an extra quantity of oil to these countries but remain mindful of its possible existence.

Table I also shows the distribution of crude oil by API gravity. Data are derived from Meyer, ${ }^{4}$ from Petroconsultants S.A., and from personal communication with many interested persons. The aggregate data base is almost complete for most countries, and at the regional level, the data are entirely credible. As shown in Fig. 2 and Table I, 89\% of conventional world oil is lighter than $25^{\circ}$ API gravity: $57 \%$ lies between $25^{\circ}$ and $35^{\circ} \mathrm{API}$, and $32 \%$ is lighter than $35^{\circ}$ API. Actually, we have no basis for the specific subdivisions shown; needed is a technical rationale for classification - the data apparently are available.

\section{METHODOLOGY FOR ASSESSMENT OF UNDISCOVERED RESOURCES OF CRUDE OIL}

Undiscovered economically recoverable resources of crude oil (Table I) were assessed for this study by utilizing the techniques employed by the USGS for domestic petroleum assessment. ${ }^{6}$ In general, the intent is to estimate economically recoverable resources, but in the case of very deep water and of Arctic/Antarctic ice conditions, we have assumed eventual economic recovery for large-field occurrence, even though technical capability may not yet be demonstrated.

The assessment technique requires study of a given area, paying particular attention to the geologic factors controlling the occurrence, quality, and quantity of the petroleum resource. Standardization of critical elements of the investigations is achieved by the preparation of data forms for each basin which call for specific volumetric, areal, and rock-quality measurements, as well as the determination of basin analogues for comparison. In addition, finding-rate histories and projections are constructed whenever possible. The absence in some areas of reliable dry-hole data is a problem that unquestionably weakens the assessment process and may result in a high-side bias to the assessment. From these data and analyses, a set of 
TABLE I

World estimate of Original Recoverable Resources of conventional crude oil. Units: $10^{9}$ tonnes

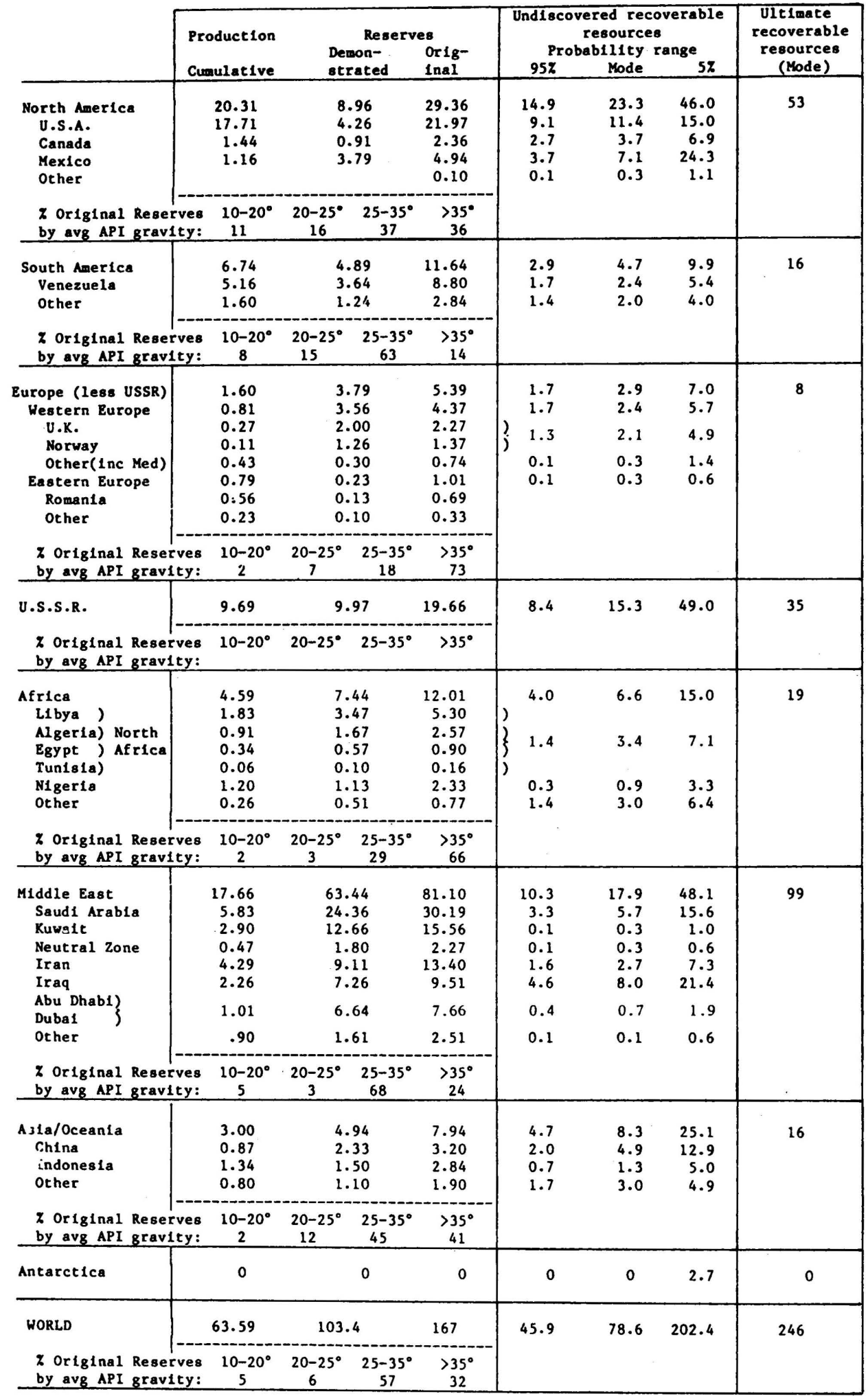

Authors: Masters, C. D., Root, D. H., Dietzman, W. D.
Date: Reserves and production as of $1 / 1 / 81$ Und 1 scovered Resources as of $3 / 83$ 


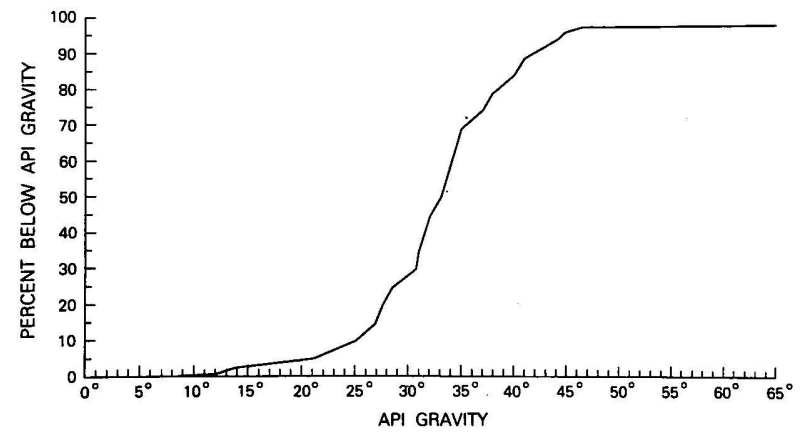

Fig. 2. Distribution by API gravity of world's Original Reserves of crude oil. (API gravity $=141.5 /$ specific gravity-131.5).

resource numbers is calculated by making volumetric comparisons with different analogue basins, by projecting discovery and production curves, and/or by play analysis.

The assessment process itself is subjective; the results of the geological investigation and of the resource calculations are presented to a team of USGS assessment specialists (in this case, a team of 10 to 12 scientists, each on average having about 20 years of petroleum studies experience), each of whom makes his personal estimates conditional upon economically recoverable resources being present. Initial assessments are made for each of the assessed provinces as follows:

(a) A low-resource estimate corresponding to a $95 \%$ probability of more than that amount.

(b) A high-resource estimate corresponding to a $5 \%$ probability of more than that amount.

(c) A modal (most likely) estimate of the quantity of the resource associated with the greatest likelihood of occurrence.

The individual estimates are then posted and averaged and the results debated from the perspectives of the personal experiences of the individual assessors. A second and third iteration of the procedure may follow depending on consensus. If no commercial oil has yet been discovered in the basin, a marginal probability is subjectively assessed to record the probability of any commercial oil being present. The results of the final estimates are averaged, and the numbers are computer-processed using probabilistic methodology ${ }^{7}$ to show graphically the range of the economically recoverable resource values.

Approximately $90 \%$ of the world's undiscovered resources of crude oil were assessed in this way over a period of about 3 years utilizing approximately 18 man-years. (For an example of one of several publica- tions, see Ref. 8.) Many small basins, or those considered after preliminary examination to have limited petroleum potential, were assessed on the basis of exploration or production projections or by cursory volumetric and analogue determinations. In our judgement, no area having significant crude-oil potential remains unassessed at this stage of data development and availability.

\section{ANALYSIS OF ESTIMATES OF RESERVES OF CONVENTIONAL CRUDE OIL AND THEIR DISCOVERY RATES}

Because reserves by definition are economic and because economics varies with the perspective of the operator, unavoidable inconsistencies exist in reserves reporting. Some world reserves estimates, however, appear to be clearly too low and others arguably too high. That the series of numbers reported, for example, in Ref. 9, is likely too low is evidenced by the following analysis: (1) The amounts of oil discovered over the past 10 years, as reported for this study (Fig. 3) or by Exxon, ${ }^{10}$ are considerably

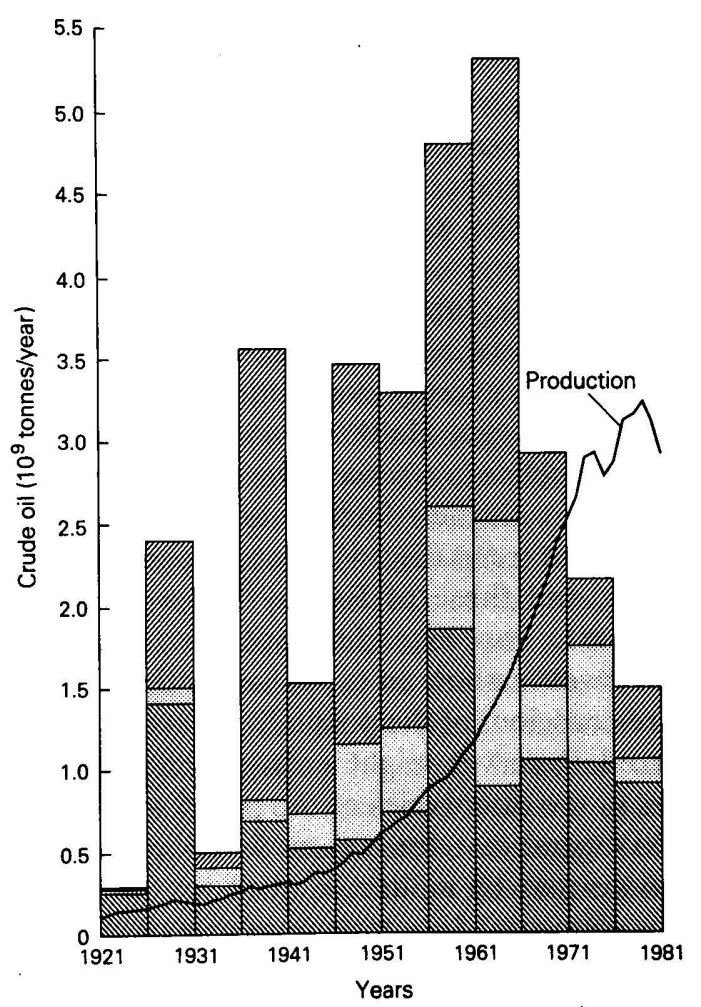

Fig. 3. World crude-oil discovery rate averaged over 5-year periods, $1 / 1 / 21$ to $1 / 1 / 81$. Top: Middle East. Middle: Eastern Europe, USSR, Asia, and Oceania. Bottom: Western Europe, Africa, and Western Hemisphere. Annual production is also shown. Units $=10^{9}$ tonnes $/ \mathrm{yr}$. 
less than the amounts of oil produced over the same period. We show the differential to be about $\mathbf{1 1 . 4}$ GTO over the 10-year period, whereas Exxon shows it to be about 8.6 GTO. Whichever data set proves to be most nearly correct, there would seem to have been a deficit for the 10-year period of about 10 GTO. (2) During this same period, the reserves reported in Ref. 9 did not decline but rather increased by about 5.9 GTO. (3) Reserves, therefore, must have been larger than stated or they grew, through additions from the Inferred Reserves, by at least 15.9 GTO. The conundrum is how much longer we will be able to re-evaluate upwards because of improved recovery practices or because of new pools and unpredicted field extensions (Inferred Reserves) enlarging the Demonstrated Reserve. On a smaller scale, in the United States during the last 10 years, production exceeded discoveries by more than 3.1 GTO, yet reported reserves declined by only about 1.7 GTO. A possible explanation for this lies in the USGS estimate of 3.3 GTO of Inferred Reserves. ${ }^{6}$ The United States clearly is the most extensively explored and developed region in the world, yet the data show the need for revisions of the reserves reporting, year by year, on the order of $0.14 \mathrm{GTO}$, or one-third of our annual production. It is important for us to learn where that oil is coming from because some day that cushion is going to be exhausted; it is equally important, for the same reasons, that we establish, on the world scale, a known relationship between discovery, production, and reserves.

Contrariwise, some reserve numbers appear to us, definitionally, to be too high, because the authors assumed $40 \%$ average conventional recovery. ${ }^{11}$

Four years ago, Halbouty and Moody ${ }^{11}$ reported a modest decline in reserves over the previous decade; we concur with their findings and with the continuation of that trend (Fig. 4). We also concur with their findings, and those of Exxon, ${ }^{10}$ of a declining discovery rate now extending over two decades. Our data, however, show an even sharper decline (Fig. 3); we are conscious of the possibility that additions from Inferred Reserves might enlarge the reserves estimates of the discoveries of the past 5 or 10 years but would suggest that, for reasons described above, those additions may be modest.

The elements of accurate reserves reporting appear to be within our grasp. In a few countries, understanding of definitions and availability of public data for independent analysis are still lacking, but overall we are confident that these estimates are proportionally and geographically satisfactory. Specifically unaccounted for is an unassessed quantity of Indicated

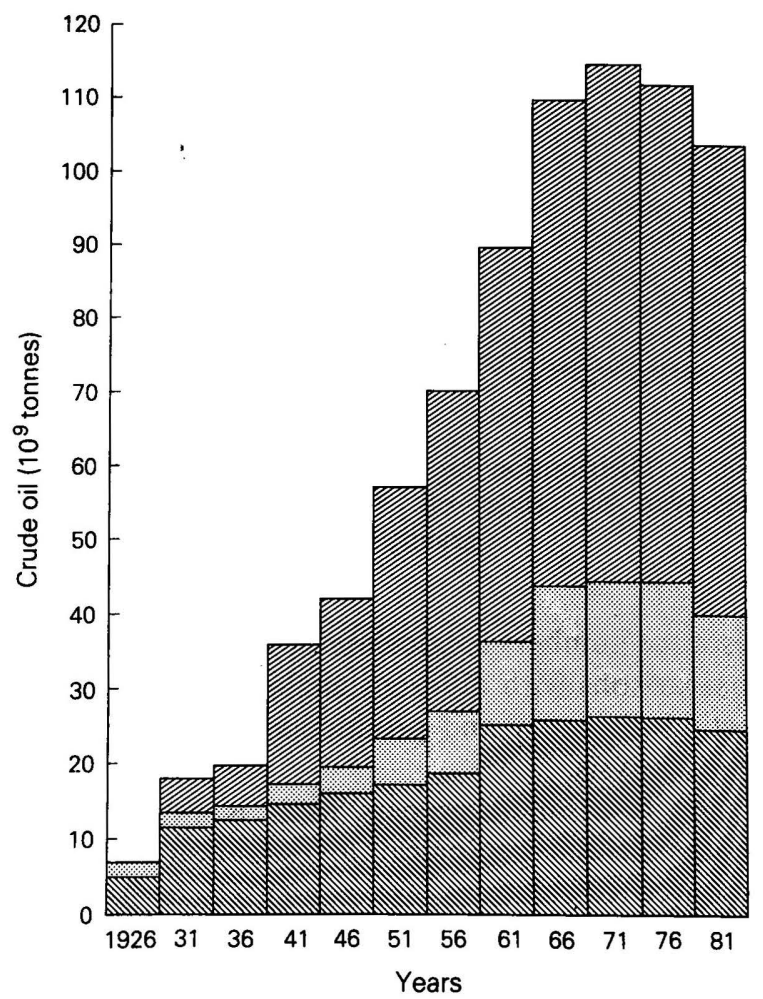

Fig. 4. Demonstrated Reserves of crude oil in 5-year intervals, 1/1/26 to 1/1/81. Top: Middle East. Middle: Eastern Europe, USSR, Asia, and Oceania. Bottom: Western Europe, Africa, and Western Hemisphere. Units: $10^{9}$ tonnes.

Reserves, as described above, along with some Inferred Reserves in the form of new pools and unpredicted extensions of known reservoirs; we believe the quantities unaccounted for can be no more than a few percent of the total and likely could be assessed statistically, given greater certainty in production and discovery data.

\section{ANALYSIS OF THE UNDISCOVERED RESOURCES OF CONVENTIONALLY RECOVERABLE CRUDE OIL}

Our assessment of the world potential for Undiscovered Resources of conventionally recoverable crude oil indicates a $90 \%$ probability that the value lies between 46 and 202 GTO, with a most likely (modal) value being 79 GTO (Table I). Our assessment $(95 \%$ to $5 \%$ probability range) falls inside the range ( $90 \%$ to $10 \%$ probability range) assessed by Halbouty and Moody ${ }^{11}$ of 40 to 345 GTO, and our modal value is significantly less than their expected 
value of $141 \mathrm{GTO}$. Whereas comparison of the estimates by region (Fig. 5 of this paper and Table 4 of Ref. 11) discloses remarkable similarities in the modal assessments of the United States and of the Middle East, the other world subdivisions show considerable differences. Because the areas corresponding to the assessments are not the same, however, it is not possible to be precise about where all the differences lie. Nehring ${ }^{12}$ has recently published a disaggregated reserve and resource analysis with which we find we are in substantial agreement, both with respect to total numbers and to regional distribution of crude oil. Because of reporting differences, however, a dialogue is nonetheless required to ascertain the conceptual differences between oil additions deriving from discovery, as opposed to oil additions deriving from increased recovery.

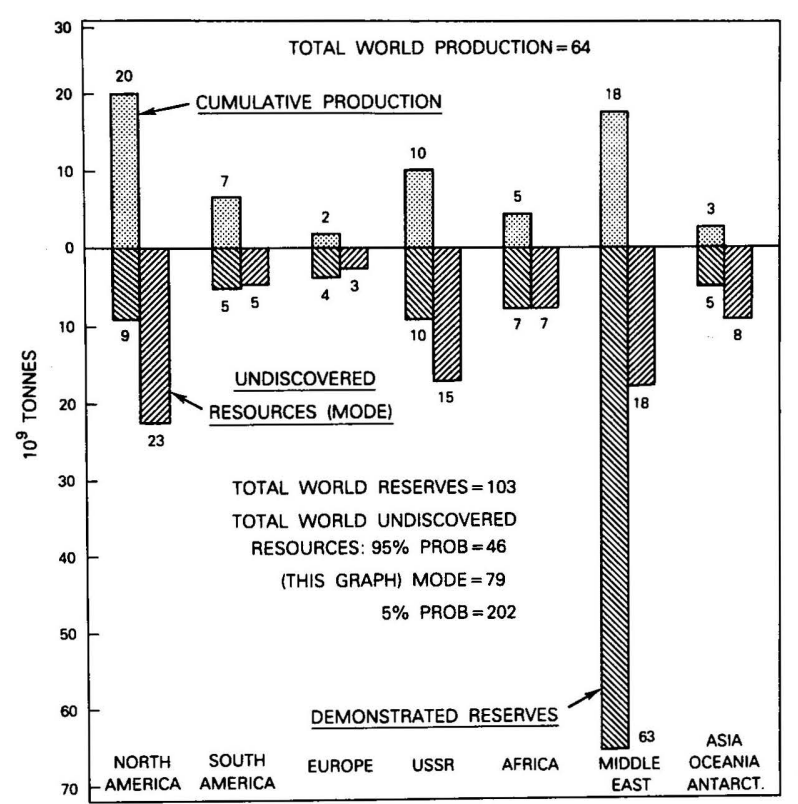

Fig. 5. Regional distribution of Demonstrated Reserves and cumulative production of crude oil as of $1 / 1 / 81$ and the mode of undiscovered resources as of $3 / 83$. Units: $10^{9}$ tonnes.

A further difference between the assessment provided to the Tenth World Petroleum Congress and this assessment lies in the high-side values which differ by a factor of almost two. Our view at this point is that world data are fully adequate to support a relatively narrower range of resource estimates. To achieve the higher of the two assessments, a discovery of the dimensions of another Middle East province clearly must be considered, and our studies indicate no possibility for such an occurrence.

The low-side assessments, on the other hand, remain essentially identical. They, of course, reflect the potential of relatively well known provinces, and the assessment process has, in this case, the advantage of more complete information.

For our modal assessment of 79 GTO of Undiscovered Resources to be sustained, a massive amount of exploration is still required. We have not completed the studies of trends of finding-rate efficiencies, but our general perception is that numbers of exploratory wells are increasing yet discoveries are declining; hence, exploration efficiency is also declining. Needed to reverse that decline is the discovery of new major provinces (ultimate resources in excess of 3 GTO or one year's production for the world), or significant discovery increases in the giant Middle East province or in others of the identified petroleum-favourable regions of the world. Our analysis suggests the likelihood that most of the new oil will come from the established provinces, but the unknown of the Arctic, deep water, and other frontier areas always must remain a consideration.

In attempting to address the issue of contributions of frontier basins to new oil discovery, we tried to analyse the often repeated notion that there are a certain significant number of still untested basins. We have not yet completed the work to permit a comprehensive statement, but we can note that most of these basins are untested for good geologic or economic reasons. In particular, we examined the Arctic region for clues to the prediction of undiscovered major provinces. The region is so big that it is awkward to downgrade almost any part for lack of favourable oil characteristics. However, we do not think that the evidence is encouraging, for example, for any significant extension under the Barents Sea of the highly favourable Devonian source rock of the Volga Urals basin or the mature Jurassic source rock of the North Sea basin; in all other areas of the Arctic, likewise, there does not appear to be that combination of geologic factors necessary for truly large oil occurrence. On the basis of area and volume alone, a significant amount of oil must be assessed for the Arctic, but we see little possibility there for the discovery of a major province. In addition, the Arctic poses logistic and environmental problems that necessarily will deter commercial development.

The deep-water areas remain poorly known. Although an attempt was made to extend geologic understanding of coastal regions out to a water depth of $2500 \mathrm{~m}$, we must acknowledge inconsistency in this 
effort. Certainly, data become sparse in deep-water regions, but in most areas we also judge that the merit of the petroleum geology declines as well.

Our still limited understanding of China reflects, in part, only the time constraints for preparation of this paper. There is much published literature to be digested and vast minimally drilled areas to be tested. Nonetheless, it has been possible to develop a broad, general understanding of China's petroleum geology sufficient to render a credible assessment (Table I). Published regional analyses are excellent, and sufficient quantitative data are available to begin to get an idea of their reserves, the dimension of their basins, and various other specific petroleum geology parameters. The most critical data still missing are drilling results to permit exploration-maturity analysis.

\section{OTHER OCCURRENCES OF OIL RESOURCES-EXTRA-HEAVY CRUDE OIL AND BITUMEN}

Though large quantities of extra-heavy crude oil and bitumen are known in various parts of the world, ${ }^{4}$ these commodities are not at present serious economic contenders in the market. We suggest, therefore, that the issue is not how much is in the ground but rather how much can be produced. Considering that production facilities have a finite service life, we define reserves as the amount of oil that can be produced over a 25-year period given installed production facilities; the otherwise recoverable resources are classified as Marginal Reserves; the remainder of the in-place resources, considering approximately a $10 \%$ recovery factor, is shown as Subeconomic Resources (Fig. 6). Though considerable quantities of bitumen are available in different parts of the world, only in Canada, from the Athabasca tar sands, is a major extraction effort under way-now producing approximately 7.9 MTO/yr. The overwhelmingly dominant resource of extraheavy oil is in the Orinoco heavy-oil belt of Venezuela; on a pilot-plant basis, some $0.4 \mathrm{MTO}$ are being produced. Elsewhere in the world, annual production of $0.4 \mathrm{MTO} / \mathrm{yr}$ is also being achieved in Italy and $0.14 \mathrm{MTO} / \mathrm{yr}$ is being produced in both the United States and in Mexico, for a total extra-heavyoil production of 1.1 MTO/yr. Extra-heavy oil and bitumen cannot contend economically with conventional crude oil, but their presence in large quantities in various parts of the world assures mankind of the essentially limitless availability of naturally occurring oil.

\section{CONCLUSIONS}

There is an immense quantity of conventional crude oil in the world; our capacity for consumption, however, is perfectly capable of challenging that immensity. Though there is much yet to be discovered and produced, there is no room for complacency. The slack is coming out of reserves estimates, and to the extent that discoveries remain less than production, world Demonstrated Reserves, as defined herein, will

ORIGINAL MEASURED RESOURCES OF EXTRA-HEAVY OIL AND BITUMEN

\begin{tabular}{|l|c|c|}
\multicolumn{2}{|c|}{ AREA $:$ WORLD } & UNITS : $10^{9}$ TONNES \\
\hline \multirow{2}{*}{$\begin{array}{l}\text { CUMULATIVE } \\
\text { PRODUCTION }\end{array}$} & BITUMEN & 0.032 \\
\cline { 2 - 3 } & EXTRA-HEAVY OIL & 0.061 \\
\hline \multirow{2}{*}{ RESERVES } & BITUMEN & 0.03 \\
\cline { 2 - 4 } & EXTRA-HEAVY OIL & 8 \\
\hline \multirow{2}{*}{ MARGINAL } & BITUMEN & 25 \\
\hline \multirow{2}{*}{$\begin{array}{c}\text { RUBECONOMIC } \\
\text { RESOURCES }\end{array}$} & EXTRA-HEAVY OIL & 71 \\
\cline { 2 - 4 } & BITUMEN & 214 \\
\hline
\end{tabular}

AUTHOR: MEYER, R. F.

DATE : 1983

Fig. 6. Classification of Original Measured Resources of extra-heavy oil and bitumen as of 1983 . Units: $10^{9}$ tonnes. 
continue to decline. Even if EOR and the production of extra-heavy oil and bitumen become ubiquitous reality, they are unlikely to achieve rates of production even close to matching those of primary and secondary recovery in the past; the resulting patterns of consumption of crude oil in the decades ahead, then, will be quite different.

The distribution of crude oil remains restricted, and there is little chance that that condition will change (Fig. 5). The Middle East region dominates known world petroleum occurrence, and we judge it still to be the richest hunting ground. Even though most of the world's oil will continue to be supplied from traditional areas, exciting discoveries of great local significance will be made in many other areas of the world. However, one should not anticipate riches from so-called untested areas just because exploration activity has not been obvious.

A further concern about estimates of world petroleum availability is the present limited discovery rate relative to production. Without evaluating in detail the geology of all exploration activity, the general level of exploration, as measured by numbers of wells, has increased over time, yet annual discoveries are declining, suggesting the possible reality of lowside assessments. If the low side be reality, the need for alternate energy sources becomes increasingly critical for most of the world's countries.

\section{ACKNOWLEDGEMENTS}

, The authors wish to express their appreciation for the indispensable support of the many research associates involved in the preparation of this report. In reserve studies: T. A. Ross and N. R. Rafidi, US Energy Information Administration. In resource studies: A. B. Coury, R. R. Charpentier, J. W. Clarke, R. A. Crovelli, G. L. Dolton, J. Kingston, K. Y. Lee, J. A. Peterson, K. Robinson, E. W. Scott, US Geological Survey; H. D. Klemme, GeoBasins Ltd.;
G. Ulmishek, Argonne Laboratory; D. Gill, Geological Survey of Israel; and J. P. Riva, Jr., Library of Congress. In heavy oil and bitumen studies: R. F. Meyer, USGS. In addition, the authors include in this paper, without modification, the assessments for the United States and Canada prepared respectively by the Resource Appraisal Group of the US Geological Survey and the Petroleum Resources Appraisal Secretariat of the Geological Survey of Canada.

\section{REFERENCES}

1. US Bureau of Mines and US Geol. Survey, Principles of a resource/reserve classification for minerals, US Geol. Survey Circ. No 831, 1980, 5p.

2. US Energy Information Admin. 1981 Ann. Rpt., DOE/EIA-0216(81), 1982, US Govt. Printing Office, $121 \mathrm{p}$.

3. Amer. Petrol. Inst., Amer. Gas. Assoc., and Canad. Petrol. Assoc. Reserves of crude oil, natural gas liquids and natural gas in the U.S. and Canada as of Dec. 31, 1979, API 34, 1980, Washington D.C., 253 p.

4. Meyer, R., Wynn, J. and Olson, J. (eds), Heavy crude and tar sands. McGraw Hill, Chapter 16 (in press).

5. Dietzman, W. D. et al., Middle East-crude oil potential from known deposits. Rpt. No. DOE/EIA-0298, 1981, US Govt. Printing Office, 143 p.

6. Dolton, G. L. et al., Estimates of Undiscovered Recoverable Conventional Sources of Oil and Gas in the United States, US Geol. Survey Circ. No. 860, $1981,87 \mathrm{p}$.

7. Crovelli, R. A. Procedures for petroleum resource assessment used by the U.S. Geological Survey-statistical and probabilistic methodology. US Geol. Survey Open-File Rept, 23 p. (in press).

8. Masters, C. D. et al., Assessment of undiscovered Recoverable Resources of the Arabian-Iranian Basin, US Geol. Survey Circ. No. 881, 1982, 1-12.

9. Amer. Petrol. Inst., Basic Petroleum Data Book, Washington D.C., 1981, 1 (3), Sect. 11, Table 1.

10. Exxon Corp. Public Affairs Dept., World energy outlook, New York, 1982, 40 p.

11. Halbouty, M. T. and Moody, J. D., 10th World Petrol. Congr., 2, 291-301.

12. Nehring, R., Ann. Rev. of Energy, 7, 1982, 175-200. 




